\title{
Making Sense of Divides and Disconnects in a Preservice Teacher Education Program
}

\author{
Karen Goodnough \\ Memorial University of Newfoundland \\ Thomas Falkenberg \\ University of Manitoba \\ Ronald Macdonald \\ University of Prince Edward Island \\ Elizabeth Murphy \\ Memorial University of Newfoundland
}

Authors' note

This study was made possible by a grant from the Social Sciences and Humanities Research Council of Canada. We are grateful to the reviewers and the editor for their valuable insights and suggestions.

Correspondence concerning this article should be addressed to Karen Goodnough at kareng@mun.ca

\begin{abstract}
This study's purpose was to make sense of divides and disconnects in a teacher education program that included university-based courses combined with school-based field experiences. The study took place in Québec, Canada, which has the longest practicum of all provinces and programs designed to develop professional autonomy and competency. Data collection relied on documents, interviews, surveys, and focus groups with 44 preservice teachers along with field supervisors and instructors. Analysis relied on cultural historical activity theory and its principle of contradictions. Findings revealed that contradictions resulted in unintended and unfavourable outcomes such as teacher candidates feeling unprepared and untouched by the program. Resolution of contradictions may be realized through expansion of the division of labour to include more peer and self-assessment and through expansion of tools to support boundary crossing between theory, practice, schools, and university.
\end{abstract}

Keywords: Preservice teacher education; cultural historical activity theory; contradictions; school-university partnerships; divides and disconnects 


\section{Making Sense of Divides and Disconnects in a Preservice Teacher Education Program}

A central feature of preservice teacher education programs in Canada is "they all have a practicum component that is distinct from the university-based course work" (Falkenberg, 2010, p. 10). Practicum experiences represent a "central and relevant component of teacher preparation" (Broad \& Tessaro, 2009, p. 79). Numerous benefits have been associated with such field experiences including "the development of pre-service teachers' efficacy levels and teaching skills" (Gurvitch \& Metzler, 2009, p. 438). A combination of school- and universitybased learning, sometimes referred to as school-university partnerships, can potentially contribute to teacher education reform (Burton \& Greher, 2007) and can benefit both the school and the university (Walsh \& Backe, 2013).

In spite of their benefits, however, programs that include both university and schoolbased experiences may be characterised by divides (Anagnostopoulos, Smith, \& Basmadjian, 2007) and disconnects (Bullough, Draper, Smith, \& Birrell, 2004; Valencia, Martin, Place, \& Grossman, 2009; Zeichner, 2010). These may occur between teacher education programs and "the daily lives of schools" (Caillier \& Riordan, 2009, p. 495) or between schools as places "for practical elements of training" and universities as the "site of theory" (Aldridge, 2015, p. 111).

Divides and disconnects may manifest themselves as "gap[s] between preparation and practice" (Russell, McPherson, \& Martin, 2001, p. 40) or as "dissonance between knowledge developed in the academic program and candidates' experiences in the field placements" (Gambhir, Broad, Evans, \& Gaskell, 2008, p. 200). Regardless of how they manifest themselves, they may result in negative outcomes. An example of a negative outcome is teacher candidates (TCs) not being able to address the ambiguities that arise in integrating theory and practice and beginning teachers facing "problematic situations for which they were not sufficiently prepared" (Korthagen \& Wubbels, 2001, p. 32). Identification and potential resolution of the divides and disconnects can minimize the negative outcomes. However, given the complexity associated with supporting TCs in learning to teach, identification and resolution of the divides and disconnects may be difficult to achieve.

\section{Using CHAT to Make Sense of Divides and Disconnects}

One approach to the identification and resolution of divides and disconnects is to adopt a framework that brings order and coherence to otherwise complex phenomena in teacher education programs. A framework can support and scaffold systematic and holistic analysis of the many complex components of these programs that combine, interact and potentially contradict each other. Cultural historical activity theory (CHAT) and its principle of contradictions provide such a framework. Few studies in teacher education have thus far relied on CHAT (Jahreie \& Ottesen, 2010, p. 214) to understand the complexities of teacher education; however, interest in CHAT is growing in teacher education research (Anagnostopoulos, Smith, \& Basmadjian, 2007; Wilson, 2014). It is beyond the scope of this article to describe CHAT's origins, principles, and frequent application in areas such as health care, social work, and human computer interaction. The work of Yamagata-Lynch (2010) provides a detailed overview and explanation of CHAT particularly in relation to teacher education. 


\section{The Activity System as Unit of Analysis}

Using a CHAT framework to analyze disconnects and divides in a teacher education program involves conceptualizing the program as an activity system. As an activity system, the education program is viewed as a group of subjects that work towards an object using tools according to particular norms in a community and with a given division of labour. In a CHAT framework, the subject represents the point of view of the group or individual whose agency is the focus of the analysis. In a teacher education program, the subjects would be individuals such as TCs, instructors, or field supervisors. Activity systems exist for a purpose and are driven by an object, which constitutes the motive of activity (Leont'ev, 1981) and "the raw material or problem space at which the activity is directed" (Center for Activity Theory and Developmental Work Research, 2003-2004). The object is the sense maker that makes evident the purpose of activity or the "ultimate reason behind various behaviors of individuals, groups, or organizations" (Kaptelinin, 2005, p. 5). For example, the object of a teacher education program might be, in general terms, to prepare individuals to teach in the K-12 system.

The subject's pursuit of the object is mediated by tools. Tools may be psychological and symbolic such as theories and strategies or they may take physical forms such as computers or textbooks. Practice is a tool and means of enacting particular behaviours in a given context to achieve a particular object. The subject shares pursuit of the object within a community. For example, TCs as subjects in a teacher education program participate in activity along with individuals such as instructors and supervisors. Subjects within communities must conform to the norms of the activity. In the context of teacher education, these norms may require that TCs participate in university-based courses along with field-based experiences. The subjects participate within a particular division of labor or hierarchy of roles, responsibilities and power. For example, TCs will be expected to follow policies and regulations set by schools and the university. As the subjects pursue the object, there may be intended outcomes (e.g., TCs develop strong teacher identities) or unintended outcomes (e.g., TCs struggle in their field experiences).

Activity systems are typically depicted using a triangle (see Engeström, 1987) that illustrates the subject working towards the object using tools within a community according to a division of labour and norms with intended and/or unintended outcomes.

Figure 1. Activity System

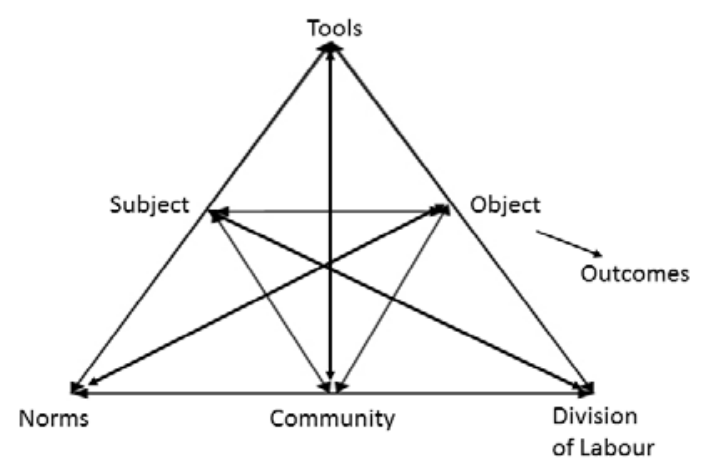

Figure 1. A depiction of the activity system with its interrelated and interacting components. (Engeström, 1987, p. 78) 


\section{Contradictions}

According to CHAT, the outcomes in an activity system result from interactions within and between components in the activity system. Unintended outcomes and failure to realize the object result from contradictions. Contradictions are manifestations of disconnects, divides, disturbances (Engeström, 2001, p. 137), conflicts (Dippe, 2006), or misfits, ruptures, breakdowns and clashes (Kuutti, 1996, p. 34). They represent "deviations in the observable flow of interaction" in the activity system (Engeström, Brown, Christopher, \& Gregory, 1991, p. 91). Contradictions are more than merely tensions or challenges; they cannot be observed directly but can be identified through their manifestations (Engeström \& Sannino, 2011). They represent "a situation which permits the satisfaction of one end or result at the expense of the other" (Hartwig, 2007, p. 81). Contradictions play a vital role as "the motive force of change and development" (Engeström \& Miettinen, 1999, p. 9) and can result in "deliberate collective change effort[s]" (Engeström, 2001, p. 137) and "innovative attempts to change the activity" (p. 134). Resolution of contradictions can lead to expansive transformations, which represent "a radically wider horizon of possibilities than in the previous mode of activity" (Engeström, 2001, p. 137) and a more developed state (Engeström, 2009).

\section{Purpose}

The purpose of this article is to make sense of the divides and disconnects in one teacher education program in Canada. Our analysis relies on a CHAT framework to (a) portray the activity system of a teacher education program from the perspective of the TCs, (b) identify contradictions, and (c) determine possible means of resolution of the contradictions.

The focus on divides and disconnects is not like an evaluation program. Evaluations are concerned with establishing "the merit, worth, quality, or value of programs... at the request of some client or clients, and for the benefits of some audience" (Scriven, 1994, p.75). The specific focus on contradictions is not meant to suggest a deficit perspective of the teacher education program in this study or of other teacher education programs. Rather, it is meant to provide another lens, through CHAT and its principle of contradictions, to make sense of the divides and disconnects that may arise in teacher education. In this framework, contradictions are viewed as normal in all activity systems, as a potential source of innovation, and as a means to transform the system to a more culturally and socially advanced mode

\section{Studies Using Contradictions to Analyse TCs’ Activity}

Some studies have relied on CHAT to analyze teacher education programs, reporting primarily on the perspectives of teacher educators and mentors rather than TCs (e.g., Anagnostopoulos, Smith, Basmadjian, 2007; Waitoller \& Kozleski, 2013; Williams, 2014). Some, such as Valencia et al. (2009), have focused on TCs in post-graduate master degree programs as opposed to undergraduate degree programs, as in this study. Others have referred to "tensions" without grounding them in the principle of contradictions (e.g., Smagorinsky, Cook, Moore, Jackson, \& Fry, 2004). Still others (e.g., Stillman \& Anderson, 2011) have interpreted contradictions merely as tensions or conflicts, that is, manifestations of contradictions but not contradictions themselves. In our review of the literature conducted for this article, we identified two studies with TCs as subjects in an undergraduate preservice teacher education program, which analysed the activity system in terms of contradictions. 
One of these, a study conducted by Tsui and Law (2007), took place in China with two mentors, two instructors, and two TCs. The study investigated how a lesson study tool enhanced TCs' learning, how it generated contradictions, and how these were resolved. A contradiction arose between the need to simultaneously support the TCs and enhance learning. Lesson study was adopted by the supervisors and cooperating teachers to resolve this contradiction and was designed to shift evaluation from the individual TC to the lesson itself. However, contradictions emerged in the division of labour with an "unequal power relationship" between TCs on one hand and the "assessors" on the other (p. 1298).

Additional contradictions emerged within the lesson study tool itself that was "collectively prepared" but "individually enacted" (Tsui \& Law, 2007, p. 1298). Although the new tool was meant to resolve contradictions, it also created new contradictions. Resolution of the new contradictions was achieved by evolving a new object: the "professional development of both novices and experts" (Tsui \& Law, 2007, p. 1300). As Tsui and Law (2007) concluded, "The new mediating tool transformed the learning experience: the participants came to a new understanding of their roles in the activity system, established a new relationship, and participated in the discourse in a different way" (p. 1300).

Dang's (2013) study focused on the development of professional identity of two TCs of English in Vietnam in a context of a paired placement. Dang investigated the "collective journey" of the TCs by mapping the trajectory of their zone of proximal development (Vygotsky, 1978) "in terms of contradictions and their resolution in their joint activity system" (p. 49). Dang categorized data in terms of the components of the activity system prior to identifying contradictions, a process also followed in this study. Dang identified contradictions between subject and object as a conflict between perceptions of student teaching in terms of student learning versus following the lesson plan. Another contradiction between the subject and division of labour involved an "unequal power relationship" whereas the final contradiction involved "different levels of appropriation of pedagogical tools" (p. 53). The study revealed that, as the subjects' awareness increased, "contradictions were recognised and fully or partially resolved" (Dang, 2013, p. 57).

Our study differs from these two in its more deliberate and dedicated focus on contradictions themselves and in its attention to divides and disconnects in preservice teacher education. Dang's (2013) purpose was similar to ours in that she was interested in identifying the contradictions as well as their potential for resolution. Compared to these studies, our study provides a detailed portrait of the activity system in terms of the various components in order to identify the origins of all contradictions in the system. Unlike these other studies, ours was the only study uncovered in the review that was conducted in a North American context.

\section{Research Design}

\section{Context}

This article reports on one case that was part of a larger, multi-year, pan-Canadian study conducted in undergraduate teacher education programs in five universities in western, central and eastern areas of the country. The purpose of the larger study was to identify how teacher education programs, structures, practices, and pedagogy support teacher candidates in connecting and integrating practical knowledge, theory, and experience. This study moves beyond a focus 
on only theory and practice to identify divides and disconnects, including those between theory and practice, in an interrelated complex context of object-oriented activity.

This article focuses on one case of a teacher education program in the province of Québec. This was a relevant context in which to make sense of divides and disconnects since Québec's practicum is the longest in Canada with a minimum 700 hours or 125 days of practice (Crocker \& Dibbon, 2008). The practicum makes up 30\% of the program time with 70\% devoted to university-based courses (Russell, Martin, O'Connor, Bullock, \& Dillon, 2013). Québec's teacher education programs also provide a unique context in which to consider issues pertaining to divides and disconnects because of the required emphasis on professionalism and competency. Martinet, Raymond, and Gauthier (2001) explained that Quebec's teacher education programs focus "not only on a better integration between theoretical and practical courses, but also between practical courses and the actual conditions in which future teachers will practise their profession" (p. 24). This integration is fostered by a focus on professionalization that "breaks away from traditional university training” (p. 17), presenting, in Martinet et al.'s (2001) words, a "departure in the field of education" (p. 28).

TCs are expected to work towards increasingly high levels of professional autonomy by using 12 competencies. These competencies are a "codified practical knowledge that can be transmitted by training" (Martinet et al., 2001, p. 18), that is, knowledge applied "in a real-life classroom context, during placements" (Martinet et al., 2001 p. 24). Competencies are concerned with "how to do things" (p. 302) and "the technicalities of teaching" (Thomas \& Desjardin, 2013, p. 316). A competency-based approach in teacher education "calls for a revolution" because universities remain "structured for traditional knowledge transmission," yet competencies cannot be transmitted but "must be constructed by teacher candidates in contextualised, realistic learning contexts" (Thomas \& Desjardin, 2013, pp. 303-304) such as the practicum.

\section{Data Collection}

Overview. The analysis of the activity system adopted the TCs as subject. The data collected from supervisors, instructors and the program director helped corroborate and triangulate the portrait of TCs' activity system. While data from cooperating teachers would have enriched the data set, it was not possible to collect this data. The study relied on multiple sources of data, including individual and paired interviews, focus groups, a survey, and document analysis. All data collected from interviews and focus groups were transcribed. Table 1 provides a summary of the data collection along with an overview of the quantity collected in terms of word counts. 
Table 1

Summary of Data Collection

\begin{tabular}{|c|c|c|}
\hline Data sources & Participants & Transcribed word counts \\
\hline \multirow[t]{5}{*}{ Individual interviews } & 7 course/seminar instructors & $\begin{array}{l}\text { Lowest: } 2498 \\
\text { Highest: } 6830 \\
\text { Total: } 35,514 \\
\text { Average: } 5073\end{array}$ \\
\hline & Program director & 7585 \\
\hline & $1 / 44 \mathrm{TC}$ & 8198 \\
\hline & $1 / 44 \mathrm{TC}$ & 4687 \\
\hline & $1 / 44 \mathrm{TC}$ & 6806 \\
\hline Paired interview & $2 / 44 \mathrm{TCs}$ & 5728 \\
\hline Written survey & $\begin{array}{l}44 \text { TCs (including those } \\
\text { interviewed) }\end{array}$ & 7678 \\
\hline \multirow[t]{2}{*}{ Focus groups } & 12 field supervisors & 11,625 \\
\hline & $5 / 44 \mathrm{TCs}$ & 12,238 \\
\hline Document analysis & $\begin{array}{l}\text { Sample courses } \\
\text { Program description } \\
\text { Practicum description } \\
\text { Ministry documents } \\
\text { Program website }\end{array}$ & \\
\hline
\end{tabular}

Interviews. The interviews relied on what Gall, Gall, and Borg (2003) refer to as the informal conversational interview. This approach involves "the spontaneous generation of questions in a natural interaction" (Gall, Gall, \& Borg, 2003, p. 239). The informal conversation supports building rapport between interviewer and interviewee. Such rapport may allow the interviewees to speak more openly, particularly in a context where they may have concerns that their comments will be read by colleagues. Each interview began with the interviewer gathering information about the interviewee, such as her name and role in their program. Early in the interview, the interviewer asked the interviewee to talk generally about the role of theory and practice in teacher education programs. The remainder of the interview focused on the program at the university, the courses, practicum experiences, and individual experiences, as well as relationships between groups such as faculty and cooperating teachers and field supervisors. There were 11 individual instructor interviews and one interview with two individuals (paired interview).

Focus groups. There were two focus groups, each lasting approximately 60 to 90 minutes. One focus group was held with field supervisors and the other with two TCs. The focus group facilitator questioned supervisors about their experiences of the program and the 
practicum, about the types of support they provide and their perceptions of what might ideally benefit the TCs in terms of their development during the practicum. The facilitator also led a discussion about the role of theory. During the focus group, participants could question each other, change topics, and add additional ideas. The facilitator's role was to keep the discussion focused, to probe, to ask for clarification, and to ensure participation by all participants.

Survey. A paper-format survey administered by a research assistant after class was completed by 44 TCs. Topics for the survey included participant perceptions of the role of theory and practice in their program, how they experienced each of these in their program, examples of how their program integrates theory and practice, and how the program might strengthen theorypractice relationships. The 10 TCs who participated in the interviews or focus group were a voluntary subset of the group of 44 who completed the survey.

Document analysis. Document analysis included review of the content for one course and the syllabi of other courses. Analysis also included the detailed content in the program website that featured information about the program design, the mechanisms for practicum placement, and the roles of personnel such as field supervisors. Additional documents included the province's ministerial documents regarding the requirements for and direction of teacher education programs.

\section{Data Analysis}

The analysis relied on a CHAT framework that "provides a means for observing the emergence of patterns in human activity" (Hashim \& Jones, 2007, p.14). The CHAT analysis, therefore, relied on deductive and inductive approaches. In relation to the former, and, using the activity system as the unit of analysis, there were seven predetermined components into which the data were categorized. Within each category (e.g., tools), analysis, then, involved inductive identification of patterns using related keywords and concepts. A CHAT analysis was conducted from the perspective of a subject whose agency is selected as the point of view in the activity system, in this case, the TCs. Table 2 presents the coding scheme.

Table 2

Activity System Components and Defining Questions for Coding

\section{Component Defining question}

Subject
Whose agency is selected for the analysis?
Thect
Thats the problem or motivator of activity?
Norms
How do the subjects use the tools to achieve the object?
Community
Division of Labour $\quad$ How are tasks and power divided for subjects in the activity?




\section{Data Reporting}

Participants' comments are labeled using the acronyms TC, FS (field supervisor), IN (instructor and/or program director) combined with a number (e.g., FS1). The 10 TCs who participated in the interviews and focus groups are labelled as $\mathrm{TCa}, \mathrm{TCb}$ and so on, whereas responses to the survey are labelled as TC1-44. To promote confidentiality, references to the participants are made using the feminine pronoun.

\section{Findings}

\section{Portrait of the TCs' Activity System}

The portrait reveals subjects working towards an object (purpose) by using tools according to certain norms within a community and according to a division of labour. The portrait also reveals the outcomes of the subjects' attempts to realize the object. The portrait of the TCs' activity system reflects a generalised portrayal of the case based on the data available for analysis by the researchers. As is the case with any qualitative sampling from a larger population, the portrait may not be representative of all TCs, instructors, or field supervisors participating in the program.

Object. TCs are enrolled in a program that aims to "train" teachers to become competent, autonomous teaching professionals who "apply and validate theoretical knowledge" (Ministère de 1'Education, du Loisir et du Sport, 2008, p. 12). TCd articulated what being a competent teacher meant for her: "Teach me to be a good teacher. I want to get up there and be absolutely comfortable, and not just teaching the material.... I just want to know how to make it fun, make it interactive for the kids." IN6 argued that TCs were focused on "classroom management." She added, "Without a doubt that's what they all want to know." The TCs' "want to get into the classroom.... [As a result,] the theory part is sometimes problematic for them" (IN3). Likewise, $\mathrm{TC} \mathrm{j}$ argued, "There's so much to learn that people don't want to waste time. People want to be in the classroom. They want it so bad that all this academic focus sometimes may be a little bit heavy." At the same time, that practical experience adds a pressure of evaluation. Not surprisingly, as IN8 argued, "All they want is to pass. So, they'll do anything to please the supervisor."

Subject. The TCs enter the program with varying abilities, backgrounds, and experiences. With regard to theory, some TCs "come in very suspicious" (IN4) and "very raw" (IN7). IN7 commented that they "just aren't at a stage where they're ready to learn it yet." TCh added that "some are just very young.... [and] don't have the maturity ... because [they're] coming in straight from school." If they have not had an opportunity to observe children, "they can have a very naïve understanding" (TCh). TCi described TCs as "really, really shy" and "not even comfortable" teaching in front of their peers.

Tools. For TC15, practice occurred through "field experiences mostly." However, TC41 perceived that "there isn't really much practice [because] courses are theory based." Particularly, in the case of general and foundation courses, according to TC24, there may be "too much theory 
[and] not enough practice." Theory may be perceived as "not always relevant," "extremely redundant," (TC3) or "over-emphasized" (TC24). IN2 commented that theory "without being in the role of a teacher-it's in one ear and out the other almost." TC38 observed that same theories are taught in multiple classes resulting in repetition. TC20 experienced theory using readings, literature, PowerPoint presentations, lectures, textbooks, term papers, assignments and "a lot of material...that they may never use." IN1 described the methods and professional seminar courses as "much more directly tied to the practice in the field." IN1 added that other foundational and general courses such as Philosophy of Education "are a little bit more removed and also tend to be taught by people who aren't familiar with the school system."

The seminar courses accompany the field experiences and provide an opportunity to focus on the competencies that, according to $\mathrm{TCi}$, make "really concrete what we have to be as teachers." The competencies are something they "really work on a lot" and cover "everything that they need to know more, or to develop to go into teaching" (IN8). One TC's comments highlighted the importance of the competencies as follows: "Do I think of theory? I think of the competencies. I'm really aware of them. I read them a lot because that's what I'm evaluated on" (TCi). The seminar courses also focus on the development of a portfolio. The portfolio is "based on the twelve professional competencies .... [and includes] "a recent philosophy statement... diplomas, certificates and $\mathrm{CVs}, \ldots$... extremely good lesson plans or good units,... feedback from students, feedback from CTs [cooperating teachers], [and] PowerPoints that they created" (IN8). Assessment of the TCs is carried out by supervisors and cooperating teachers using models of professional competency along with a competency rubric.

Norms. In Years 1 and 2, TCs are primarily attending university courses. TCg perceived that, in their foundational and general courses, students are often "dealing with . . theory." TCc described her experiences as follows: "Most of our classes are pure theory, pure lecture format. We're just sitting mindless[ly] listening to the teacher, taking notes..." In the first two years, they experience observation periods in the schools during which time they are "exposed to all the aspects of the school" (FS1) and "observe different teaching styles" (IN8). In Years 3 and 4, they teach up to $100 \%$ of their time in the school. In conjunction with each practicum period, they have one professional seminar in which they "prepare good lesson plans" (IN8). They can "practice it [the lesson plan] in the methods class and actually go out and enact it with the students in their class" (IN5). Besides working on their portfolio in this seminar course, they do "a lot of discussion, based on ... what they went through during the week" in their practicum (IN8). In the seminar courses they "do a lot of group work" (TCh) and some peer teaching.

Community. FS1 observed that, "It could happen that there's only one student teacher in that whole school. It's a lonely place to be." IN8 noted a similar isolation: "We never meet the supervisors, so I don't know who the field supervisors are." Likewise, the field supervisors may not always "know what goes on in the seminars" (FS2). IN1 commented that there is a need and intent to create the connections between the cooperating teacher, supervisor, TCs, and course instructors, but "due to time, resources, and getting people together, that's really difficult to do." IN1 concluded, as a result, there are "a lot of the theory-to-practice gaps - that's why they're happening. Because the people teaching the courses are ... disconnected from what's going on in the schools"

Division of labor. IN1 explained that faculty cannot always design programs to best meet TCs' needs because of "all these politics." TCs and faculty personnel must adhere to the program 
guidelines and policies articulated by the Ministère de l'Education, du Loisir et du Sport. Likewise, IN3 argued that instructors are "constrained by the rules of the university," which can limit TCs' classroom activity. FS1 argued that TCs can "be really lucky and get a real[ly] good cooperating teacher or they could get a terrible cooperating teacher. It's the luck of the draw." IN5 noted that, if the TC is unlucky, she may be with a cooperating teacher who teaches "in a very traditional way." For example, IN7 described a "student who is enamored with this kind of teaching and learning [constructivist]... and they have a teacher who is very, 'This is how it's done..." TCe described the practicum as "a luck game, a crapshoot." She related the experiences of peers who "taught the way that their teacher wanted them to teach."

Outcomes. IN2 argued that some TCs are "almost untouched by this program by the time they finish." This perspective is corroborated in particular by TCc who described her reaction after looking at her transcript, seeing a particular course and realizing she "couldn't remember anything." She added, "I could not tell you anything — not one thing that I learned or even what happened in that class. It's a complete blank. So it had no effect on me at all." IN2 commented that TCs "dismiss lots of the coursework because it's too idealistic and doesn't deal with the realities of classrooms." As a result, in the words of TCb, "you definitely tune out. The first few classes, if I feel it's repetitive, I don't listen at all." Tuning out can result in experiences like those of TCg who argued that "nothing actually sort of sinks in. You get out into the field and it's like whoa, all of a sudden, all the theory goes out the door." TCd echoed this experience regarding her upcoming final field experience: "I just feel.... I'm going to be lost a little.... I just don't feel ready...I'm going to have a job next September and I feel like I'm going to be left on my own." TCb described how, during her practicum, she was taught about what "happens" in a classroom, yet "that didn't really happen. I was there for four months and I have seen nothing like that. It doesn't necessarily match." In the words of TC26, "There is a disconnect between what is taught, the theory aspect that is, and what is occurring in actual classrooms."

Referring to the practicum, IN8 argued, "That's probably where they learn the most." TC1 articulated this perspective as follows: "It is through my field experience that I learned the most....Practice gives us a chance to experiment [with] it for ourselves and determine our strengths and weaknesses." However, as IN7 observed, during their practicum, some TCs may be "very frustrated, and ... scared because they have to succumb to following their teacher's way." FS6 commented that the workload may be "very heavy for them." FS4 explained that the TCs are "trying to juggle everything else and often not given a lot of leeway-No dispensations because they're doing their practice teaching." 
Figure 2. Summary of TCs’ Activity System

\begin{tabular}{|c|c|c|}
\hline \multicolumn{3}{|c|}{$\begin{array}{l}\text { TOOLS } \\
\text { Practice field experiences; foundation, general and methods' courses; theory; observation } \\
\text { periods; lectures; seminars; lesson plans; professional competencies; term papers; } \\
\text { assignments; portfolio; readings; models \& forms for evaluation of competency. }\end{array}$} \\
\hline $\begin{array}{l}\text { SUBJECT } \\
\text { Shy; young; suspicious of } \\
\text { theory; straight from school; } \\
\text { inexperienced with teaching } \\
\text { naive understanding of child }\end{array}$ & $\begin{array}{l}\text { OBJECT } \\
\text { Become co } \\
\text { validate the } \\
\text { learn to be } \\
\text { pass. }\end{array}$ & $\begin{array}{l}\text { ompetent, autonomous teaching professionals; apply \& } \\
\text { eoretical knowledge; practice teaching in the classroom; } \\
\text { comfortable managing the classroom; please the supervisor; }\end{array}$ \\
\hline $\begin{array}{l}\text { NORMS } \\
\text { Attending courses; dealing } \\
\text { with theory; taking notes; } \\
\text { listening to lectures; } \\
\text { observing; teaching in the } \\
\text { practicum; preparing \& } \\
\text { practicing lesson plans; } \\
\text { doing group work \& peer } \\
\text { teaching in methods \& } \\
\text { seminar courses. }\end{array}$ & $\begin{array}{l}\text { COMMUNITY } \\
\text { University instructors } \\
\text { \& personnel; } \\
\text { cooperating teachers; } \\
\text { field supervisor; school } \\
\text { students \& personnel; } \\
\text { peers. }\end{array}$ & $\begin{array}{l}\text { Feeling unprepared for practicum; learned more from } \\
\text { practicum than from courses; untouched by program; } \\
\text { tuned out; theory goes out the door; mismatch between } \\
\text { what is learned and what is lived in classroom; juggling } \\
\text { a heavy workload; frustration. } \\
\text { DIVISION OF LABOUR } \\
\text { Adherence to politics, policies and guidelines from } \\
\text { ministry, university, department, \& schools. TCs } \\
\text { dependent on evaluation of competencies by field } \\
\text { supervisor \& cooperating teacher; TCs following } \\
\text { the teacher's way. }\end{array}$ \\
\hline
\end{tabular}

\section{Contradictions}

The contradictions that emerged in this study were within the object as well as between the object and the subject and between the object and the tools, the norms, the community, and the division of labour. One of "most basic concepts" (Kaptelinin, 2005, p. 4) of CHAT is that of the object. Activity systems are object oriented, working towards predetermined desirable outcomes. First, the historically developed, generalized object serves as "the institutional answer to societal needs ... and institutional structures" (Jahreie \& Ottensen, 2010, p. 216). In the context of the teacher education program in this study, this generalized object was to become competent, autonomous, teaching professionals who can apply and validate theoretical knowledge. Second, the "situational, constructed object" is a "partial manifestation of the generalized object" and reflects the subjects" "individual motives and interests for being involved in the activity" (Jahreie \& Ottensen, 2010, p. 216).

Object and object: Autonomous, competent professionals versus pleasing the supervisor. There is a contradiction between the generalized versus the situational object. Acting to please the supervisor is at odds with acting autonomously according to a framework of professional competencies. Competency involves knowing how to act in a given context (Jonnaert, 2002; Roegiers, 2004). Autonomy, in a context of teaching, involves teachers actively engaged in making decisions "by doing their own thinking, by setting their own goals, and by doing their own plans" (DeVries \& Zan, 1994). Acting to please others has been identified in other studies. For example, Moore (2003) found that "preservice teachers often adopted the style and method expressed by the mentor teacher regardless of whether they were in conflict with theory or practice suggested in the university classroom....rather than risk disapproval of the mentor teacher" (p. 40).

Subject and object: Young, inexperienced, and naive versus comfortable managing of the classroom. TCs want to learn to be comfortable managing the classroom. However, 
particularly for those in the early years of the program, their young, naive, and inexperienced nature may interfere with or prevent them from being comfortable managing the classroom. Classroom management may be challenging for TCs who have had little experience with children and who themselves may be young. Powell (1992) finds that TCs with "fewer life experiences" and "limited work experience" (p. 236) were more likely to be influenced by former learning experiences and by former role models. If, as Powell (1992) argues, the complexity of teaching is "grounded in prior schooling experiences, personal features, and life experiences" (p. 235), then, young and inexperienced TCs may lack the prerequisites for achieving the object of being comfortable managing the classroom.

Tools and object: Theory versus competence. As required by the ministry, "for all supervisors, the framework of competencies should constitute an indispensable tool for supervising and evaluating student teachers" (Ministère de l'Education, du Loisir et du Sport, 2008). The framework serves as a tool for the evaluation of the competencies. Although application and validation of theory was an object for the program, there was no tool provided for its evaluation in the practicum such as a model, principles, or a rubric. Thomas and Desjardins (2013) argued, "The focus on competency-building can be seen as a response to the frequent criticisms that teacher education was far too theoretical and did not prepare teachers to act professionally" (p. 298). Thomas and Desjardin (2013) posited, "It is also possible for this strong focus on the development of competencies and the knowledge of how to act in context can have the effect of diminishing the importance of theoretical and content knowledge in teacher education programmes" (p. 301). In this case, participants' perspectives suggest that the overt focus on competencies in the practicum overshadowed a focus on the application and validation of theory.

Division of labour and object: Dependence versus professional autonomy. The object of professional autonomy means that teachers must learn "to assemble and combine knowledge, attitudes, techniques and strategies (tactics) to perform specific tasks.... within a network of constraints, and must design realistic solutions to deal with the problems they encounter" (Martinet et al., 2001, p. 18). This type of spontaneous and self-driven action is at odds with a division of labour in which TCs are dependent on the supervisor's and cooperating teacher's evaluation. The exercise of autonomy is also compromised in situations where TCs may be practicing in a classroom that belongs to someone who is partly responsible for their evaluation. Bullock and Russell (2010) described TCs being evaluated on the "ability to mimic" certain behaviours expected by the cooperating teacher. Dang (2013) also observed an "unequal power relationship" (p. 98). This "power differential" between the TC and cooperating teacher (Gambhir et al., 2008) can interfere with TCs' exercise of autonomy and agency. Not surprisingly, Rodgers and Chaillé (1998) concluded that "most preservice teachers have not experienced classrooms where they were encouraged to solve their own problems, develop their own questions and search for answers, or use critical analysis and reflection to develop their own ideas about issues" (p. 2).

Community and object: Isolation versus professional partnerships. Martinet et al. (2001) argued that professionalization requires partnerships, shared visions, and collaborative structures (p. 18). Some TCs in our study perceived that they did not experience a community that allowed for strong partnerships or shared visions. In the university setting, some TCs reported feeling isolated from school professionals. In the schools, some reported feeling isolated from their peers. Instructors and supervisors did not always meet and were always not aware of 
what was happening in each other's context. This isolation is also identified in the literature. As Zeichner (2010) argued:

It is very common for cooperating teachers with whom students work during their field placements to know very little about the specifics of the methods and foundations courses that their student teachers have completed on campus, and the people teaching the campus courses often know very little about the specific practices used in the P-12 classrooms where their students are placed. (p. 91)

Norms and object: Courses versus application and validation of theory. TCs are expected to apply and validate theory, yet some TCs described spending time in university-based coursework where examples of theory-practice connections were not strong. Zeichner (2010) described this as "a perennial problem" in terms of a "lack of connection between campus-based, university-based teacher education courses and field experiences" (p. 91). Martinet et al. (2001) noted a need for "better integration between theoretical and practical courses, but also between practical courses and the actual conditions in which future teachers will practise their profession" (p. 24).

\section{From Contradictions to Boundary Crossing and Expansion}

Divides and disconnects in preservice teacher education programs are a manifestation of contradictions in an activity system deeply rooted in history and tradition. They derive from "taken for granted ... cultural assumptions about how things are done and how relationships are managed" (Capper \& Williams, 2004, pp. 9-10). The fact that contradictions are based on assumptions and are taken for granted makes them that much more resistant to potential resolution. However, CHAT sees recognition and resolution of contradictions as an opportunity to promote a more culturally and socially advanced form of practice. One approach to the resolution of contradictions involves boundary crossing and expansion of components in the activity system, namely, tools and the division of labour.

Boundary crossing and expansion of tools. Boundary crossing refers to "ongoing, twosided actions and interactions between contexts" and offers "a potential process of transformation [of] ... current practices ... motivated by and directed toward the problem space that binds the intersecting practices together" (Akkerman \& Bakker, 2011, p. 148). Boundary crossing between campuses and schools may be represented by hybrid or third spaces that serve as alternatives to "traditional ways of organizing" (Zeichner, 2010, p. 92). These spaces or tools may include teachers-in-residence programs, hybrid teacher educator positions, clinical laboratories, community-based field experiences, campus-based laboratory schools, and schoolbased methods courses. The creation of these spaces, Zeichner (2010) argued, involves rejecting binaries as "competing discourses" and bringing "practitioner and academic knowledge together in less hierarchical ways to create new learning opportunities for prospective teachers" in relationships that are "equal and more dialectical" (p. 92). The teacher education program in this study included third spaces in addition to the practicum in the form of the seminar, methods courses, observation, and portfolio. An expanded role for these tools in teacher education programs could potentially support more boundary crossing.

Representations of teachers' practices. Other tools that may support boundary crossing include representations of teachers' practices (Zeichner, 2010). The representations can be brought into courses and may be particularly relevant for inexperienced TCs or those not familiar 
with children or the classroom. Representations can scaffold analysis of practice, problemsolving and critical thinking. They serve a similar purpose as observation but offer additional affordances. For example, TCs watching a video of authentic teaching can stop to discuss or to reflect at any time during the observation. They can also replay segments and go at an individual pace. One advantage of representations is that teacher educators can do as Zeichner (2010) recommended, which is to "create representations of their own teaching of elementary or secondary students" (p. 93) for use in campus-based courses.

Simulations of classroom situations (Zeichner, 2010) are another means of representing practice. Forms of simulation of practice include role-play, unrehearsed dramatization, immersion in scenarios and case studies (Goldenberg, Andrusyszyn, \& Iwasiw, 2005). The latter involve "actual problems encountered by practitioners. Learners analyze and discuss cases, retrace and critique steps taken by the characters, try to deduce outcomes, and apply didactic content and theory to the case" (Goldenberg, Andrusyszyn, \& Iwasiw, p. 310). Digital simulations are now possible because of opportunities provided by information and communication technologies (ICTs). Interactive video, YouTube ${ }^{\mathrm{TM}}$, virtual worlds and games represent some approaches to reliance on ICTs to simulate practice and the world of teaching. Simulations can be tailored to the characteristics of TCs in order to take into account their level of experience and age. Zeichner (2010) also recommended modeling by K-12 teacher educators as a form of boundary crossing. Modeling can support representation of classroom practice.

Boundary crossing can be supported by tools described by Darling-Hammond and Snyder (2000), which foster movement "from intellectual understanding to enactment in practice" (p. 525). Such tools may take a form similar to the competencies and include models and rubrics to monitor, scaffold, and assess application and validation of theory. Darling-Hammond and Snyder (2000) advocated authentic forms of assessment that integrate "multiple kinds of knowledge and skill," and collect "multiple sources of evidence" (p. 527). These might take the form of "case reports" that add "context to theory" (p. 529), exhibitions of performance that evaluate abilities "in relation to articulated standards of practice" (p. 534), or "problem-based inquiries into concerns arising from work with children and families" (Darling-Hammond \& Snyder, 2000, p. 540).

Expansion of the division of labour. Another tool that can support boundary crossing is video. For example, Baecher, Kung, Jewkes, and Rosalia (2013) relied on digital video records of teaching along with rubrics to help TCs better understand evaluation of classroom practice and to "build readiness for self-evaluation" (p. 196). Baecher et al. (2013) found that reliance on video with peer evaluation could "enhance and scaffold the path from supervisor to selfevaluation" so that "...supervisors may be able to be utilized to a greater extent in a mentoring or coaching role" (p. 196). In the teacher education program studied in this context, peer and selfassessment would require expansion of the division of labour. Baecher et al. (2013) outlined the benefits of this approach: "By incorporating self, as well as supervisor, evaluation early in their professional preparation programs, candidates gain practice in applying standards to their teaching that encourages an active stance in the evaluation process" (p. 189).

\section{Conclusion}

Drawing on data from a program in the Canadian province of Québec, this article illustrated that, rather than merely a disconnect between university and school or between theory and practice, 
divides and disconnects were manifestations of more complex underlying contradictions. These contradictions made evident the role that the object or purpose played in the divides and disconnects. In this study, the contradictions were identified within the object and between the object and each of the other components within the system. The divides and disconnects resulted in unintended and unfavourable outcomes such as TCs feeling unprepared and untouched by the program and learning more from the practicum than from the courses.

The analysis pointed to expansion of the tools to support boundary crossing as a means of resolving the contradictions. Expansion involved incorporating tools for evaluation of application and validation of theory, for representing and simulating practice, and tools for demonstrating and practicing. Expansion of tools can include reliance on modeling, role-play, dramatization, and case studies as additional university-based classroom strategies and on concrete measures for assessment such as video and rubrics. Expansion of the division of labor might involve reliance on tools for peer and self-assessment.

\section{Limitations}

As with any study in a real context of learning, there are limitations that readers should keep in mind when interpreting the findings of the study. We did not conduct observations. The data, therefore, represent participants' perspectives and perceptions of their experiences. In terms of validity, the perspectives presented may not necessarily be representative of all TCs, instructors, and field supervisors involved with the program. It was beyond the scope of the study to collect data from cooperating teachers. Their perspectives may have provided a further opportunity to triangulate data from other sources. Regarding the issue of generalizability, the study involved only one program that cannot be considered representative of all programs in Québec or in Canada. However, readers can compare the study's findings with their particular context to determine whether they may be relevant to their own teacher education programs.

\section{Implications}

In terms of implications for research, this study has demonstrated the value of focusing on the object or purpose in order to understand divides and disconnects in teacher education programs. The study has also highlighted the value of thinking of teacher education programs as activity systems with components that interact and potentially contradict each other. Future studies may focus on the field supervisors, instructors, or cooperating teachers as subjects. Such studies may approach divides and disconnects as two separate activity systems that share boundaries and that benefit from boundary crossing. More research into tools for representing practice may support boundary crossing in university-school partnerships. In terms of practice, instructors and field supervisors can experiment with expansion of tools to include more opportunities for boundary crossing. In relation to policy, the findings point to the potential role of assessment in bridging divides and disconnects related to the division of labour. Departmental policies may offer a means to promote opportunities for TCs' self- and peer assessment, as well as assessment of the application and validation of theory during the practicum.

\section{References}

Akkerman, S., \& Bakker, A. (2011). Boundary crossing and boundary objects. Review of Educational Research, 81(2), 132-169. doi:10.3102/0034654311404435 
Aldridge, D. (2015). The role of higher education in teacher education: A reorientation towards ontology. In R. Heilbronn \& L. Foreman-Peck (Eds.), Philosophical perspectives on teacher education. Journal of Philosophy of Education Book Series (pp. 111-131). Wiley.

Anagnostopoulos, D., Smith, E., \& Basmadjian, K. (2007). Bridging the university-school divide: Horizontal expertise and the "two worlds pitfall." Journal of Teacher Education, 58(2), 138-152. doi: 10.1177/0022487106297841

Baecher, L., Kung, S., Jewkes, A., \& Rosalia, C. (2013). The role of video for self-evaluation in early field experiences. Teaching and Teacher Education, 36, 189-197. doi:

10.1016/j.tate.2013.08.001

Broad, K., \& Tessaro, M. (2009). Voices from the field: Associate teachers and teacher candidates in learning conversations. In T. Falkenberg \& H. Smits (Eds.), Field experiences in the context of reform of Canadian teacher education programs (pp. 6778). Winnipeg, MB: Faculty of Education, University of Manitoba.

Bullock, S., \& Russell, T. (2010). Does teacher education expect too much from field experience? In T. Falkenberg \& H. Smits (Eds.), Field experiences in the context of reform of Canadian teacher education programs (pp. 91-100). Winnipeg, MB: Faculty of Education, University of Manitoba.

Bullough, R., Draper, R., Smith, L., \& Birrell, J. (2004). Moving beyond collusion: Clinical faculty and university/public school partnership. Teaching and Teacher Education, 20(5), 505-521. http://dx.doi.org/10.1016/j.tate.2004.04.007

Burton, S., \& Greher, G. (2007). School-university partnerships: What do we know and why do they matter? Arts Education Policy Review, 109(1), 13-24. http://dx.doi.org/10.3200/AEPR.109.1.13-24

Caillier, S., \& Riordan, R. (2009). Teacher education for the schools we need. Journal of Teacher Education, 60(5), 489-496. doi: 10.1177/0022487109348596

Capper, P., \& Williams, B. (2004). Cultural-historical activity theory: Enhancing evaluation using systems concepts. Washington, DC: American Evaluation. Retrieved from http:// users.actrix.co.nz/bobwill/activity.doc

Center for Activity Theory and Developmental Work Research. (2003-2004). The activity system. Retrieved from http://www.edu.helsinki.fi/activity/pages/chatanddwr/activitysystem/

Crocker, R., \& Dibbon, D. (2008). Teacher education in Canada: A baseline study. Kelowna, $\mathrm{BC}$ : Society for the Advancement of Excellence in Education.

Dang, A. (2013). Identity in activity: Examining teacher professional identity formation in the paired-placement of student teachers. Teaching and Teacher Education, 30(1), 47-59. http://dx.doi.org/10.1016/j.tate.2012.10.006

Darling-Hammond, L., \& Snyder, J. (2000). Authentic assessment of teaching in context. Teaching and Teacher Education, 16(5-6), 523-545. http://dx.doi.org/10.1016/S0742051X(00)00015-9 
DeVries, R., \& Zan, B. (1994). Moral classroom, Moral children: Creating a constructivist atmosphere in early education. New York, NY: Teachers College Press.

Dippe, G. (2006). The missing teacher: Contradictions and conflicts in the experience of online learners. Proceedings of the Fifth International Conference on Networked Learning. Lancaster: Lancaster University. Retrieved from http://www.networked learningconference.org.uk/past/nlc2006/abstracts/pdfs/P38\%20Dippe.PDF

Engeström, Y. (1987). Learning by expanding: An activity-theoretical approach to developmental research. Helsinki: Orienta-Konsultit.

Engeström, Y. (2001). Expansive learning at work: Toward an activity theoretical reconceptualization. Journal of Education and Work, 14(1), 133-56. Retrieved from http://www.tandfonline.com/doi/abs/10.1080/13639080020028747

Engeström, Y. (2009). The future of activity theory: A rough draft. In A. Sannino, H. Daniels, \& K. D. Gutiérrez (Eds.), Learning and expanding with activity theory (pp. 303-329). New York, NY: Cambridge University Press.

Engeström, Y., Brown, C., Christopher, L., \& Gregory, J. (1991). Coordination, cooperation and communication in the courts: Expansive transitions in legal work. The Quarterly Newsletter of the Laboratory of Comparative Human Cognition, 13(4), 88-97.

Engeström, Y., \& Miettinen, R. (1999). Activity theory and individual and social transformation. In Y. Engeström, R. Miettinen, \& R. Punamäki (Eds.), Perspectives on activity theory (pp. 19-38). Cambridge, UK: Cambridge University Press.

Engeström, Y., \& Sannino, A. (2011). Discursive manifestations of contradictions in organizational change efforts: A methodological framework. Journal of Organizational Change Management, 24(3), 368-387. http://dx.doi.org/10.1108/09534811111132758

Falkenberg, T. (2010). Introduction: Central issues of field experiences in Canadian teacher education programs. In T. Falkenberg \& H. Smits (Eds.), Field experiences in the context of reform of Canadian teacher education programs (pp.1-50). Winnipeg, MB: Faculty of Education, University of Manitoba.

Gall, M., Gall, J., \& Borg, W. (2003). Educational research: An introduction (7th ed.). Boston, MA: A \& B Publications.

Gambhir, M., Broad, K., Evans, M., \& Gaskell, J. (2008). Characterizing initial teacher education in Canada: Themes and issues. Prepared for the International Alliance of Leading Education Institutes. Retrieved from https://www.oise.utoronto.ca/ite/UserFiles/File/CharacterizingITE.pdf

Goldenberg, D., Andrusyszyn, M-A., \& Iwasiw, C. (2005). The effect of classroom simulation on nursing students' self-efficacy related to health teaching. Journal of Nursing Education, 44(7), 310-314. Retrieved from http://search.proquest.com/openview/bee9ca7d164f2e4e5b93ea93cb9ecdeb/1?pqorigsite $=$ gscholar 
Gurvitch, R., \& Metzler, M. (2009). The effects of laboratory-based and field-based practicum experience on pre-service teachers' self-efficacy. Teaching and Teacher Education, 25(3), 437-443. http://dx.doi.org/10.1016/j.tate.2008.08.006

Hartwig, M. (Ed.). (2007). Dictionary of critical realism. New York, NY: Routledge.

Hashim, N., \& Jones, M. (2007). Activity theory: A framework for qualitative analysis.In the 4th International Qualitative Research Convention (QRC), PJ Hilton, Malaysia.

Jahreie, C., \& Ottesen, E. (2010). Construction of boundaries in teacher education: Analyzing student teachers' accounts. Mind, Culture, and Activity, 17(3), 212-234. doi: $10.1080 / 10749030903314195$

Jonnaert, P. (2002). Compétences et socioconstructivisme. Un cadre théorique. Bruxelles: De Boeck Université.

Kaptelinin, V. (2005). The object of activity: Making sense of the sense-maker. Mind, Culture, and Activity, 12(1), 4-18. Retrieved from https://people.ucsc.edu/ gwells/Files/Courses_Folder/documents/Kaptelinin.ObjofActivit y.pdf

Korthagen, F., \& Wubbels, T. (2001). Learning from practice. In F. Korthagen, J. Kessels, D. Koster, B. Lagerwerf, \& T. Wubbels (Eds.), Linking practice and theory: The pedagogy of realistic teacher education (pp. 32-50). Mahwah, NJ: Lawrence Erlbaum.

Kuutti, K. (1996). Activity theory as a potential framework for human-computer interaction research. In B. Nardi (Ed.), Context and consciousness: Activity theory and humancomputer interaction (pp. 9-22, online version). Cambridge, MA: MIT Press.

Leont'ev, A. (1981). The problem of activity in psychology. In J. Wertsch (Ed.), The concept of activity in Soviet psychology (pp. 37-71). Armonk NY. Routledge

Martinet, M., Raymond, D., \& Gauthier, C. (2001). Teacher training: Orientations, professional competencies. Government of Québec. Retrieved from http://www.education.gouv.qc.ca/fileadmin/site_web/documents/dpse/formation_ens_a.p df

Ministère de l'Education, du Loisir et du Sport. (2008). Teacher training: Orientations for practicums in a school setting. Government of Québec. Retrieved from http://www.education.gouv.qc.ca/fileadmin/site_web/documents/reseau/formation_titular isation/FormationEnsFormMilieuPratique_a.pdf

Moore, R. (2003). Reexamining the field experiences of pre-service teachers. Journal of Teacher Education, 54(1), 31-42. doi:10.1177/0022487102238656

Powell, R. (1992). The influence of prior experiences on pedagogical constructs of traditional and non-traditional pre-service teachers. Teaching and Teacher Education, 8(3), 225-238. doi:10.1016/0742-051X(92)90022-U 
Rodgers, D., \& Chaillé, C. (1998). Being a constructivist teacher educator: An invitation for dialogue. Journal of Early Childhood Teacher Education, 19(3), 203-211. http://dx.doi.org/10.1080/0163638980190303

Roegiers, X. (2004). L'école et l'évaluation: Des situations pour évaluer les compétences des élèves. Bruxelles: De Boeck Université.

Russell, T., McPherson, S., \& Martin, A. (2001). Coherence and collaboration in teacher education reform. Canadian Journal of Education, 26(1), 37-56. doi: 10.2307/1602144

Russell, T., Martin, A., O'Connor, K., Bullock, S., \& Dillon, D. (2013). Comparing fundamental conceptual frameworks for teacher education in Canada. In L. Thomas, (Ed.), What is Canadian about teacher education in Canada? Multiple perspectives on Canadian teacher education in the 21st century (pp. 10-37). Ottawa, ON: Canadian Association for Teacher Education.

Scriven, M. (1994). The fine line between evaluation and explanation. American Journal of Evaluation, 15, 75-77. doi:10.1177/109821409401500108

Smagorinsky, P., Cook, L. Moore, C., Jackson, A., \& Fry, P. (2004). Tensions in learning to teach accommodation and the development of a teaching identity. Journal of Teacher Education, 55(1), 8-24. doi: 10.1177/0022487103260067

Stillman, J., \& Anderson, L. (2011). To follow, reject, or flip the script: Managing instructional tension in an era of high-stakes accountability. Language Arts, 89(1), 22-37. Retrieved from http://www.ncte.org/library/NCTEFiles/Resources/Journals/LA/0891sep2011/LA0891Follow.pdf

Thomas, L., \& Desjardins, J. (2013). Teacher education in Quebec: A critical examination of a competency-based programme. In L. Thomas (Ed.), What is Canadian about Teacher Education in Canada? Multiple perspectives on Canadian Teacher Education in the $21^{\text {st }}$ century. (pp. 295-319). Ottawa, ON: Canadian Association for Teacher Education.

Tsui, A., \& Law, D. (2007). Learning as boundary-crossing in school-university partnership. Teaching and Teacher Education, 23(8), 1289-1301. http://dx.doi.org/10.1016/j.tate.2006.06.003

Valencia, S., Martin, S., Place, N., \& Grossman, P. (2009). Complex interactions in student teaching: Lost opportunities for learning. Journal of Teacher Education, 60(3), 304322. Retrieved from https://cset.stanford.edu/sites/default/files/files/documents/publications/ValenciaStudentTeachingLostOpportunitiesLearning.pdf

Vygotsky, L. (1978). Mind in society: The development of higher psychological processes. In M. Cole, V. John-Steiner, S. Scribner, \& E. Souberman (Eds.), Cambridge, MA: Harvard University Press.

Waitoller, F., \& Kozleski, E. (2013). Understanding and dismantling barriers for partnerships for inclusive education: A cultural historical activity theory perspective. International Journal of Whole Schooling, 9(1), 23-42. Retrieved from http://files.eric.ed.gov/fulltext/EJ1016797.pdf 
Walsh, M., \& Backe, S. (2013). School-university partnerships: Reflections and opportunities. Peabody Journal of Education, 88(5), 594-607. doi: 10.1080/0161956X.2013.835158

Williams, J. (2014). Teacher educator professional learning in the third space: Implications for identity and practice. Journal of Teacher Education, 65(4), 315-326. doi: $10.1177 / 0022487114533128$

Wilson, V. (2014). Examining teacher education through cultural historical activity theory. Teacher Education Advancement Network Journal, 6(1), 20-29. Retrieved from http://194.81.189.19/ojs/index.php/TEAN/article/viewFile/180/294

Yamagata-Lynch, L. (2010). Activity systems analysis methods for understanding complex learning environments. New York, NY: Springer.

Zeichner, K., (2010). Rethinking the connections between campus courses and field experiences in college and university-based teacher education. Journal of Teacher Education, 61(1), 89-99. doi: $10.1177 / 0022487109347671$ 